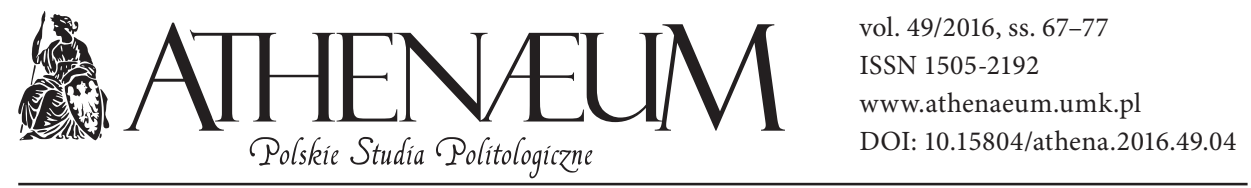

\title{
NOWE DZIENNIKARSTWO. PRÓBA REKONSTRUKCJI MODELU
}

\author{
THE NEW JOURNALISM. \\ AN ATTEMPT AT RECONSTRUCTION OF THE MODEL
}

\author{
Iwona Hofman*
}

\begin{abstract}
ABSTRAKT
Próba rekonstrukcji modelu Nowego Dziennikarstwa wynika $\mathrm{z}$ obserwacji symptomów kryzysu dziennikarstwa jako zawodu i misji (odpowiedzialność społeczna). Na podstawie wypowiedzi dziennikarzy i teoretyków można bowiem ustalić hierarchię wartości dziennikarstwa poważnego, na które jest coraz większe zapotrzebowanie społeczne. Nowe Dziennikarstwo jest najczęściej opisywane jako dziennikarstwo świadome, uwzględniające spektrum potrzeb i poglądów odbiorców, zaangażowane, niezależne, funkcjonujące w sferze publicznej, wiarygodne, pełniące rolę edukacyjną. Należy podkreślić, że cechy te odnoszą się przede wszystkim do publicystyki. W artykule uwzględniono stanowiska badawcze m.in. S. Michalczyka, B. Hennessy'ego, P. Manciniego, S. Russa-Mohla, S. Bratkowskiego, R. Kapuścińskiego.
\end{abstract}

Słowa kluczowe: poważne dziennikarstwo, profesjonalizm, kryzys mediów, wartości
ABSTRACT

An attempt at reconstruction of the New Journalism model results from the observation of the crisis symptoms of journalism as a profession and mission (social responsibility). On the grounds of journalists' and theoreticians' statements, it is possible to establish a hierarchy of values of the serious journalism, which a social demand is growing for. The New Journalism is most frequently described as the conscious journalism, which provides spectrum of needs and views of recipients. This type of journalism is committed, independent, functioning in the public sphere, credible, realizing educational role. These attributes pertain to journalism. The paper includes standpoints, for example, of S. Michalczyk, B. Hennessy, P. Mancini, S. RussMohl, S. Bratkowski, R. Kapuściński.

Keywords: serious journalism, professionalism, crisis of media, values

* Uniwersytet Marii Curie-Skłodowskiej w Lublinie, Wydział Politologii. 
Termin Nowe Dziennikarstwo pojawia się zarówno w dyskursie naukowym, jak i publicystyce przede wszystkim jako deklaratywny wyraz dezaprobaty dla pragmatyki dziennikarskiej i postulat odnowy. W Polsce, ze względu na intensywność i kumulację negatywnych cech dziennikarstwa wolnorynkowego, postulat ten towarzyszy refleksji autotematycznej. Poczynając od roku 2003, publicyści wypowiadają się krytycznie o degradacji zawodu. Przykładowo, Teresa Torańska (2013) mówiła na ten temat następująco: „Teraz pisze się lakonicznie. Szybciej zmierzamy do sedna, przez flesze, sygnały, że jesteśmy - tu i tu. Robimy akcję, a nie opisujemy. Życie przyspieszyło. Nastała cywilizacja szybkiej informacji i problemów” (s. 101), i dalej „Trzeba epatować opinią, trzymać w napięciu, a najłatwiej to się robi złymi wiadomościami” (s. 100).

Nowe Dziennikarstwo jest rozumiane w kontekście: dziennikarstwa nowych mediów, dziennikarstwa gatunków językowo-obrazowych, wartości dziennikarstwa poważnego. Odnośnie do pierwszego przypadku - wydaje się oczywiste: nowe media i nowe-nowe media zrewolucjonizowały formę, kanał przekazu oraz rolę nadawcy i odbiorcy. Wypowiedź dziennikarska nawiązująca do komunikacji wizualnej, a szerzej - kultury obrazkowej, może być rozpatrywana przez pryzmat literackiej genezy większości gatunków publicystycznych i poszerzonych informacyjnych. Wyznaczniki literackie, np. fabularyzacja, oryginalność stylu, staranność języka, subiektywizm narracji, mogą być remedium dla współczesnego nonszalanckiego sposobu uprawiania dziennikarstwa.

Wymienione propozycje interpretacji terminu naprowadzają na trop gatunku Nowego Dziennikarstwa, który wykształcił się w USA w latach 60. XX wieku pod wpływem doświadczeń pisarzy i korespondentów wojennych, m.in. Normana Mailera, Trumana Capote’a, Toma Wolfe’a. Doświadczenia te można opisać jako przeżycia nieadekwatności języka dziennikarskiego do niuansów rzeczywistości (konwencjonalne słownictwo i styl). Jak twierdził Ryszard Kapuściński (2012): „Nowe Dziennikarstwo narodziło się z kombinacji dwóch różnych dotąd sfer: realnych wydarzeń i osób, którymi karmiło się dziennikarstwo tradycyjne, oraz instrumentów i technik zapożyczonych z fikcji, wzbogacających opis faktów" (s. 7). Geneza zjawiska wiąże się z popularyzacją telewizji jako medium, którego obrazowy sposób przekazywania informacji znajdował tak wielu zwolenników, iż obawiano się (nie po raz pierwszy i nie ostatni) uwiądu prasy papierowej. Wartość Nowego Dziennikarstwa prasowego polegała na objaśnianiu i komentowaniu informacji znanych odbiorcy z wcześniejszego przekazu na ekranie. W tym ujęciu Nowe Dziennikarstwo było również odpowiedzią na zmącenie 
gatunków, powstanie hybryd gatunków, łączenie środków ekspresji właściwych różnym stylom, rodzajom itd. Nowe Dziennikarstwo to „nowa i nowatorska formuła pisania o realnych zdarzeniach i osobach z wykorzystaniem środków literackich" (Kapuściński, 2012, s. 10).

Związanie określenia Nowego Dziennikarstwa z dziennikarstwem poważnym oznacza podjęcie wyzwania przywrócenia dziennikarstwu zaufania publicznego przez odnowienie klasycznego paradygmatu dziennikarstwa jako zawodu i jako misji (o czym także pisał Ryszard Kapuściński). Rodzi się zatem nieuniknione pytanie, czy kanon dziennikarstwa, zarysowany choćby przez Kapuścińskiego czy Leopolda Ungera, jest możliwy do odtworzenia w warunkach konkurencyjności mediów i prymatu kultury masowej? Ze względu na kanoniczny wymiar Lectio Leopolda Ungera przytaczam fragment zawierający próby definiowania zawodu dziennikarza: dziennikarstwo to „zawód, a nawet, dziś w epoce telewizji, Internetu i blogów, kilka zawodów, ale to także wspólny (przynajmniej tak być powinno) dla wszystkich dziennikarzy zasób pewnych cech i wartości moralnych [...]. To specjalizacja, ale i wyobraźnia, indywidualna ambicja, ale i kolektywny zryw, pasja, ale i rozwaga, odwaga, a nawet impertynencja i złośliwość, ale i poczucie odpowiedzialności, szacunek dla godności ludzkiej" (Leopold Unger. Doktor Honoris Causa Uniwersytetu Marii Curie-Skłodowskiej, 2009, s. 22).

Do podjęcia tego tematu najmocniej zainspirował mnie opublikowany na łamach Gazety Wyborczej w 2003 roku List otwarty do Heinricha Olschowsky'ego, napisany przez Andrzeja Mencwela, w odpowiedzi na artykuł poświęcony trudnościom dialogu polsko-niemieckiego, warunkowanym historycznie, oraz toczącą się wówczas debatę wokół Centrum Przeciw Wpędzeniom. Mencwel (2009) opisał w Liście... swoje wrażenia czytelnika, charakteryzując tekst Olschowsky'ego jako: „napisany z napiętym namysłem, czujną rozwagą i psychohistoryczną [...] wnikliwością", zawierający „sentencjonalne orzeczenia” łatwo zapadające w pamięć i „wiele impulsów pobudzających refleksję, ożywiających chęć dalszych przemyśleń”. Dodał następnie: „jest to głos zasadniczo słuszny”, „podtrzymujący dialog, sam w sobie dialogowy” w tym sensie, że „wpisane są w niego [...] we wzajemnym odniesieniu pogłosy tych stanowisk, które dotąd dialog zmieniały w konfrontację”. Wreszcie wyjaśnił: „głosem swoim osiągnąłeś wszystko, co może osiągnąć publicysta - wypowiedziałeś nie tylko pewne racje, ale dałeś im także osobiste przeświadczenie [...] stworzyłeś więc wszystkim swoim pojętnym czytelnikom moralne zobowiązanie" (s. 130).

W kontekście terminu Nowe Dziennikarstwo należy wydobyć z tej charakterystyki niektóre $\mathrm{z}$ wymienionych cech: „napięty namysł i rozwagę” jako przyczynę 
podjęcia tematu, zawartość pobudzających refleksję „sentencjonalnych orzeczeń" jako efekt pracy dziennikarza, rzutujący na walory edukacyjne, dialogowość jako zestawienie argumentów lub stanowisk, umożliwiające czytelnikowi wyrobienie własnego poglądu, kompletność i komplementarność założeń, realizacji i osiągniętych celów, co rozumiem jako świadectwo wiarygodności publicysty.

Dialogowość awansuje do rangi pierwszej wartości Nowego Dziennikarstwa. Dialogowość rozumiana jako otwartość na argumentację i zróżnicowane poglądy, ciekawość świata i ludzi, gotowość wysłuchania i sztuka rozmowy. Powiedzieć można - kontemplacja problemu, co stanowi wyznacznik humanistyki. Nowe Dziennikarstwo jest lub powinno być humanizujące, skupione na potrzebach i oczekiwaniach odbiorcy, ale nie w sensie human story. Objaśniając nienachalnie świat, odnosi się ono do rzeczywistości. Zarzuca kreacyjność jako element swoistej gry badającej cierpliwość odbiorców na deformowanie (ściemnianie) obrazu świata, aż do pełnego irytacji pytania, kto, którzy dziennikarze i jakie media ponoszą odpowiedzialność za spłycenie i spłaszczenie problemów.

Nowe Dziennikarstwo to dziennikarstwo poważne, poważnie traktujące odbiorców i temat, uprawiane przez poważnych dziennikarzy świadomych celów i technik swojej pracy. Odpowiednikami tego rodzaju dziennikarstwa mogą być kategorie jakości, zaangażowania, opiniotwórczości, neutralności, lokalności, obywatelskości. Wypada dodać, że Stephen Russ-Mohl (Chyliński, Russ-Mohl, 2008) dokonał ciekawego rozróżnienia pomiędzy dziennikarstwem opiniotwórczym, skoncentrowanym na prezentacji jednego poglądu czy racji, a interpretacyjnym, które oferuje odbiorcy wachlarz stanowisk umożliwiający wyrobienie sobie własnego poglądu (s. 33), a Jan Hartman (2013) stwierdził wprost, że: „Media dla inteligencji [...] to nisza jakościowa, w Polsce to zaledwie jeden procent odbiorców produkcji medialnej" (s. 152), a więc - margines rynku.

Konstruowanie modelu Nowego Dziennikarstwa warto rozpocząć od konstatacji: dziennikarze, a przynajmniej ich część - obecna i doświadczona w mediach niezależnych (drugiego obiegu) przed 1989 rokiem - dostrzega, definiuje, postuluje utworzenie kanonu rzetelnego dziennikarstwa, utożsamiając nowe z profesjonalnym (Gawroński, Polak, 2010; zob. też: Hofman, 2010, s. 159-164, 2010a, s. 35-54, 2011, s. 63-74; Szot, 2013), gdy tymczasem brytyjski badacz mediów, Philip Elliot, nazywa profesjonalizm „sposobem mistyfikowania pewnych ról zawodowych w mediach, gdyż przymiotnik »profesjonalny « zwiększa kulturową i społeczną wiarygodność mediów i jego zdaniem, współcześnie rutynowe zadania dziennikarskie, takie jak zachowywanie zgodności z faktami, styl prezentacji, 
wyczucie wartości newsów, terminowość zyskały określenie "profesjonalnych «" (Taylor, Willis, 2005, s. 131).

Jako uwarunkowania regresu dziennikarstwa w refleksjach autotematycznych odnaleźć można: brak hierarchii informacji i ich natłok, sensacyjność, spłaszczanie obrazu świata przez rozbicie informacji na mało znaczące i bezkontekstowe cząstki, przejmowanie stylu i kultury pracy dziennikarskiej od nowych i nowszych mediów, utrata zdolności do kreowania przestrzeni istotnej debaty publicznej, brak liderów środowiska (Świat według Naczelnych, 2005, s. 15-17; zob. też: Ankieta, 2006). Cechy te ulegają zaostrzeniu w analizie roli mediów w komunikacji politycznej i publicystyki politycznej. Przykładowo, Adam Krzemiński (2011) następująco scharakteryzował teatralizację polityki na scenie medialnej: „Przykuć uwagę. Ściągnąć prominentów. Spersonalizować konflikt. Dodać efekt zaskoczenia. Pamiętać o krótkim czasie trwania widowiska. Stąd: dramatyzacja, łatwa narracja, walor rozrywkowy" (s. 34). Marc Elhardus, belgijski socjolog, nazwał te cele składowymi demokracji dramatu: „wszystko, co ważne, musi przybrać postać dramatu: z łzami, wściekłością, rozpisanymi rolami dobra i zła, tak, abyśmy mogli przywdziać szaty sędziego. Media nam w tym pomogą" (Bachmann, 2008, s. 27). Jacek Żakowski (2009) zaś o współzależnościach mediów i polityki napisał: „Wszyscy razem w obłędnym uścisku staczamy się więc coraz niżej, ciągnąc za sobą nie tylko politykę, ale też całe życie publiczne. Zmieniając wszystko w sensację, plotkę lub rozrywkę, oduczamy bowiem publiczność sensownego myślenia, a naszych bohaterów - polityków, biznesmenów, ekspertów - zniechęcamy do umysłowego wysiłku” (s. 14). W głośnym tekście Dziennikarskie ciężkie grzechy Magdalena Środa (2008) oceniła efekty opisanych wyżej zjawisk przez pryzmat etyki jako utratę przez dziennikarstwo statusu zawodu zaufania publicznego (s. 21).

Jakie zatem powinno być Nowe Dziennikarstwo, skoro „stare” (obecnie uprawiane) budzi w większości negatywne skojarzenia? Próby opisu pożądanej zmiany były już podejmowane. Obszerne ujęcie przedstawili twórcy Laboratorium Reportażu w tekście programowym Dogma Mediów, zawierającym 14 punktów rozwijających charakterystykę dziennikarstwa. Przykładowo: „Dziennikarstwo to poszukiwanie prawdy [...] analizowanie, interpretowanie i budowanie świata poprzez media [...] to narzędzie poznania”, „Dziennikarstwo to bardziej charakter, osobowość niż zawód wpisany w ankietę personalną”, „,To sztuka mediów, wielkie pole do poszukiwań i eksperymentów”, „W dziennikarstwie ważne są twórczość i rozwój. Rywalizuję sam ze sobą. Z innymi szukam porozumienia i współpracy”, „Najważniejszą rzeczą dla dziennikarza jest jego nazwisko. 
Nazwisko jest jego firmą. Na tę firmę dziennikarz pracuje całe życie [...]. Pracując na swoje nazwisko, pracuje na zawodowy etos”, „Dziennikarz to inteligent [...] odpowiedzialny za popularyzowanie pożądanych postaw i wzorów społecznych", „obowiązkiem inteligenta-dziennikarza jest popularyzacja wyższych wartości kultury i docieranie do niższych warstw $\mathrm{z}$ istotnymi treściami i problemami. To nie pouczanie i dydaktyzm, to konieczna wciąż praca od podstaw”, „Nie należy walczyć z ratingiem, należy go przejąć, czyniąc dobro wartością atrakcyjną, sensacyjną, agresywną" (Miller, 2005, s. 37-43).

Dogmie przeciwstawiony był zbiór negatywnych obserwacji dziennikarstwa, nazwany TKKT - Totalitaryzm Komercji, Konsumpcji, Transgresji. Zbiór ten w zasadzie oddaje klimat dyskusji środowiskowych. Dla potwierdzenia - przytaczam najbardziej radykalne sformułowania: „Informacja to towar. Będziemy dostarczać i sprzedawać taki towar, na jaki jest zapotrzebowanie”, „Właściwe dziennikarstwo to atrakcyjny dodatek do rządzącej nim reklamy”, „Osobowość zostaw w domu”, „Najważniejszą rzeczą dla dziennikarza jest firma: koncern, stacja, partia, gazeta - układ, któremu najwięcej zawdzięcza”, „Rating jest naszym bogiem. Lekko, łatwo, przyjemnie [...] ludzie to lubią, ludzie to kupująa" (Miller, 2005, s. 37-43). Zdaniem niemieckich badaczy, Heinza D. Fischera i Horsta Minte, gazeta ma „charakter przedsiębiorstwa produkującego miejsce na ogłoszenia, które można sprzedać tylko przy pomocy części redakcyjnej” (Chyliński, Russ-Mohl, 2008, s. 33).

Można zatem powiedzieć, że postulat Nowego Dziennikarstwa został sformułowany w opozycji do symptomów kryzysu dziennikarstwa, spowodowanego globalną ewolucją podejścia do zawodu (już nie misji) w warunkach konkurencji i swobody przepływu (generowania) informacji. W szeregu czynników sprawczych są zatem: prymat ekonomii i dyktat oglądalności, praktyka działania globalnych koncernów medialnych, tabloidyzacja mediów, mediatyzacja sfery publicznej, wymiana ról nadawcy i odbiorcy informacji, wzorzec Internetu (czas udostępnienia i format).

Model Nowego Dziennikarstwa stanowi emanację postaw kontestujących wyczerpanie dziennikarstwa. W świetle wypowiedzi dziennikarzy składnikami modelu są wysokie standardy pracy dziennikarzy, określone m.in. słowami: „humanizm naszego pisania leży właśnie w wysiłku przekazywania prawdziwego obrazu świata, a nie kolekcji stereotypów" (Kapuściński, 2003, s. 63; zob. też: Bereś, Burnetko, 2007, s. 145-146), ,jesteśmy zawodowymi pośrednikami od informacji. Mamy z tego morza dostępnych informacji wyławiać to, co uważamy za ważne, znamienne, warte przekazania i nadać mu taką formę, żeby tu dotarło 
i żeby było przyjęte” (Świat według Naczelnych, 2005, s. 11), „dziennikarz musi szukać autorytetu sam w sobie [...] sam ze sobą musi rozmawiać, sam siebie krytykować i upominać” (Ankieta, 2006, s. 8-9), „podstawą dziennikarstwa jest trzymanie dystansu do polityków [...] patrzenie na to, co robią z pewnego oddalenia. I rozliczanie ze słów, którymi nas zalewają" (Torańska, 2006, s. 35).

Należy zwrócić uwagę na wyraźny etyczny aspekt definicji, a także wyłaniającą się funkcję edukacyjną i kontrolną mediów (co pozostaje w związku z priorytetami edukacji medialnej) oraz przewartościowaniem pojęcia media czwarta władza. Obecnie twierdzi się wręcz, że media nie są czwartą władzą, lecz czynnikiem opiniotwórczym, kształtującym debatę publiczną, a więc pośrednio - kulturę polityczną i standardy demokracji (Braun, 2005); dziennikarstwo „to nie żadna czwarta władza, a antywładza, czyli mądry sceptycyzm, żeby nie powiedzieć nieufność wobec wszelkiej władzy, zwłaszcza takiej, która chce mieć rację i proponuje, jeżeli nie narzuca, bardzo proste propozycje zbawienia ludzkości" (Leopold Unger. Doktor Honoris Causa Uniwersytetu Marii Curie-Skłodowskiej, 2009, s. 22-25).

Z przeciwnej strony skonfrontować należy rozróżnienie pracownika mediów i produktu medialnego z etosem dziennikarza i etyką pracy. Pojęcie pracownika mediów dynamicznie ewoluuje: od świadczenia usług: „na świecie nikt nie żąda od »media workers«, by byli komentatorami spraw wielkiego świata albo dawali nam jakieś objaśnienia o walorze poznawczym. Rozlicza się ich $\mathrm{z}$ atrakcyjności towaru, który wyprodukują" (Kapuściński, 2003, s. 122). Do dziennikarstwa syntetyczno-scalającego, które - zdaniem Bernarda Pouleta (2011) - polega na animowaniu i kompilacji treści, dziennikarz „musi przede wszystkim umieć znaleźć informację, która jest w sieci i jest w posiadaniu innych, musi umieć ją przetworzyć, ustalić relacje i napisać na nowo, dobierając takie słowa, które umożliwią jej idealne pozycjonowanie w wyszukiwarkach” (s. 247). Mówiąc inaczej i metaforycznie: „skończył się czas, kiedy pierwsza strona Le Monde dyktowała spis treści wieczornych informacji telewizyjnych" (Poulet, 2011, s. 119), trwa zaś okres, kiedy „oprogramowanie rządzi światem” (Bendyk, 2013, s. 70-72). W dziennikarstwie internetowym możemy wręcz wyodrębnić nowe role dziennikarza, tj. nawigatora, archiwisty, moderatora (Chyliński, Russ-Mohl, 2008, s. 197).

W kontekście tych wypowiedzi, nowych argumentów dostarczyli uczestnicy niedawnej dyskusji na kanwie książki Ryszarda Kapuścińskiego (2013) To nie jest zawód dla cyników. Kluczowe w tej dyskusji wydają się odniesienia do nowych synonimów, takich jak: objaśniacz świata (dziennikarz), klikacz (odbiorca 
mediów). Objaśniacze świata są oczywiście w zaniku, gdyż współczesny czytelnik „dowiaduje się o wszystkim w ciągu minuty. Ma mniej czasu i więcej informacji do przetrawienia”, „dziennikarz staje się przewodnikiem po mapie klikania”. Zdaniem Katarzyny Kolendy-Zaleskiej (2013) wybór klikacza stanowi dowód zaufania do kompetencji dziennikarza, utrzymuje sens pracy, polegającej na pasji, rzetelności, zaangażowaniu: „Mamy swoje do wykonania: sprawdzać źródła informacji, rozmawiać z ludźmi, być na miejscu, gdzie się coś dzieje, a nie tylko czytać w Internecie o tym, co się wydarzyło [...]. Standardy się nie zmieniają. Trzeba się ich kurczowo trzymać, przekazywać je młodszym kolegom” (s. 34; zob. też: Bratkowski, 2013; Smoleński, 2013).

W świetle tych głosów wypada zdecydowanie podkreślić, że model Nowego Dziennikarstwa jest próbą rekonstrukcji sposobu przekazywania i interpretowania rzeczywistości, jaki znany jest czytelnikowi prasy wydawanej w latach 70. i 80. XX wieku, w dobie prymatu jakościowego dziennikarstwa prasowego. Kryteria jakości mediów określił wówczas Florian Fleck (1980), a już dekadę później zmodyfikował Stephan Russ-Mohl (1992) jako: zrozumiałość, aktualność/istotność, obiektywizm, interakcyjność, oryginalność (rozumianą jako własny research lub ekskluzywność tekstu), transparencję/zwrotność (rozumianą jako ocenę źródeł i okoliczności powstawania materiału) (Chyliński, Russ-Mohl, 2008, s. 366). Warto również wspomnieć o wcześniejszych, bo podjętych w latach 70. próbach określenia dziennikarstwa informacyjnego, np. Winfrieda Schulza, który stwierdził, że „wydarzenia stają się informacjami dopiero dlatego, że zostały wybrane z całości i złożoności tego, co dzieje się na świecie" (Chyliński, Russ-Mohl, 2008, s. 121), antycypując zatem - dziennikarstwo tradycyjne nie stanowi kompletnego przekazu, a jedynie wybór oparty na aktualności, ciągłości, relewancji, statusie i dynamice wydarzeń. Jak mawiał Joseph Pulitzer: „przekaż im to zwięźle, by przeczytali, jasno, by docenili, obrazowo, by zapamiętali i przede wszystkim rzetelnie, by mogli się na tym oprzeć" (Hennessy, 2009; zob. też: Skworz, Niziołek, 2010, s. 685, za: Chyliński, Russ-Mohl, 2008, s. 25).

W planie jakości dziennikarstwa muszą być uwzględnione: poziom wykształcenia dziennikarzy, etyka mediów, czynniki ekonomiczne. Triada ta oddaje rzeczywiste oczekiwania odbiorców mediów, gdyż opisuje kompetencje i przyzwoitość dziennikarską (Ankieta, 2006) w warunkach zróżnicowania rodzajowego mediów.

W desygnacie Nowego Dziennikarstwa mieści się dziennikarstwo lokalne, zmierzające w kierunku dziennikarstwa obywatelskiego. Niemiecki badacz tej problematyki, Dieter Golombek twierdzi, że media te najpełniej realizują 
funkcję kontrolną, edukacyjną i rozrywkową. Wpisują się w trendy rozwoju dziennikarstwa opartego na interakcji z odbiorcami i dostarczaniu użytecznych informacji (news you can use) (Hennessy, 2009, s. 59-68; zob. też: Poulet, 2011, s. 222). Dziennikarstwo lokalne w pewnym sensie przywraca wiarę w możliwość porozumienia społecznego. Jest wartościowe dzięki potencjałowi wiarygodnych relacji dziennikarzy, sfery publicznej i odbiorców.

Cechą zasługującą na uwagę w rekonstrukcji Nowego Dziennikarstwa jest również korelacja treści z potrzebami odbiorcy. Precyzyjnie ujął to Paolo Mancini: „dziennikarstwo świadomie skierowane do odbiorców o sprecyzowanych poglądach czy sympatiach, broniące tych poglądów, reprezentujące ludzi, którzy je podzielają, czytelnie zaangażowane" (Żakowski, 2011, s. 21). Wypowiedź ta pozostaje niejako w kontrze do kryteriów obiektywizmu i neutralności, które są najczęściej podawane w typologiach wartości informacji lub mediów. Nowe Dziennikarstwo uwzględnia więc spektrum potrzeb i poglądów odbiorców, nie poszukuje parawanów, lecz sygnalizuje wyraźnie opinię światopoglądową i reprezentację kulturową.

Na podstawie badań procesów komunikacji politycznej zespół: Dorota Piontek, Bartosz Hordecki, Szymon Ossowski (2013) rozróżnili trzy rodzaje dziennikarstwa: tabloidowe, jakościowe, tabloidalne; jakościowemu przypisali m.in. następujące parametry: wartości, wiedza ekspercka w odniesieniu do funkcji edukacyjnej; służba publiczna, racjonalność, powaga (s.116).

Najprostsze, ale i najpełniejsze sformułowanie Nowego Dziennikarstwa zauważa się w słowach ks. Adama Bonieckiego: „Media to środek komunikacji społecznej, dzięki mediom ludzie mają możliwość uczestniczenia w życiu społeczeństwa, mamy informować i pomagać zrozumieć rzeczywistość" (Świat według Naczelnych, 2005, s. 16), o ile uznamy za zasadne utożsamienie funkcji mediów z funkcjonalnością Nowego Dziennikarstwa w sferze publicznej. Wartość Nowego Dziennikarstwa polega na niezależności od i w tej sferze, a także nadrzędnego statusu wobec mediów publicznych i komercyjnych.

Dążąc do modelowego ujęcia Nowego Dziennikarstwa, można zaryzykować następujące przyporządkowania: w płaszczyźnie mikro - świadomość standardów zawodowych i etycznych, mezo - stabilizacja ekonomiczna, obecność autorytetów i/lub osobowości, przywrócenie statusu zawodu zaufania publicznego, makro - edukacyjna rola mediów, synergia z inicjatywami obywatelskimi (Michalczyk, 2008, rozdział 3). 
BibLIOGRAFIA:

Ankieta. (2006). Tygodnik Powszechny, nr 3 (2949).

Bachmann, K. (2008). Pożytki ze wścibskiej prasy. Gazeta Wyborcza, nr 138 (5748).

Bendyk, E. (2013). Oprogramowanie rządzi światem. Polityka, nr 38 (2925).

Bereś, W., Burnetko, K. (2007). Kapuściński: nie ogarniam świata. Warszawa: Świat Książki.

Bratkowski, S. (2013). Tak dobrze będzie, że nie do wytrzymania. Gazeta Wyborcza, Magazyn, nr 121 (7850).

Braun, J. (2005). Potęga czwartej władzy. Warszawa: Wydawnictwa Szkolne i Pedagogiczne.

Chyliński, M., Russ-Mohl, S. (2008). Dziennikarstwo. Warszawa: Polskapresse Sp. z o.o.

Gawroński S., Polak, R. (2010). Dziennikarstwo i komunikacja społeczna - nowe wyzwania. Kierunki zmian $w$ kształceniu $w$ zakresie dziennikarstwa $i$ komunikacji społecznej. Kraków-Rzeszów-Zamość: Konsorcjum Akademickie.

Hartman, J. (2013). Medialny stan żebraczy. Polityka, nr 17/18 (2905).

Hennessy, B. (2009). Dziennikarstwo publicystyczne. Kraków: Wydawnictwo Uniwersytetu Jagiellońskiego.

Hofman, I. (2010). Misyjność a prowincjonalizm mediów. Studia Medioznawcze, nr 4 (43).

Hofman, I. (2010a). Współczesne standardy i wyzwania zawodowe w opiniach dziennikarzy. W: B. Kosmanowa (red.), Media dawne i współczesne. T.V. Poznań: Wydawnictwo Naukowe Wydziału Nauk Politycznych i Dziennikarstwa UAM.

Hofman, I. (2011). Między komercją a misją. Standardy zawodowe dziennikarzy a współczesny rynek mediów. W: I. Hofman (red.), Studia nad dziennikarstwem. Lublin: Wydawnictwo Uniwersytetu Marii Curie-Skłodowskiej.

Kapuściński, R. (2003). Autoportret reportera. Kraków: Znak.

Kapuściński, R. (2012). Nowe Dziennikarstwo. Akcent, nr 3 (129).

Kolenda-Zaleska, K. (2013). Jeszcze żyjemy. Gazeta Wyborcza, Magazyn, nr 121 (7850). Krzemiński, A. (2011). Mediokracja. Polityka, nr 16 (2803).

Leopold Unger. Doktor Honoris Causa Uniwersytetu Marii Curie-Skłodowskiej. (2009). Lublin: Wydawnictwo Uniwersytetu Marii Curie-Skłodowskiej.

Mencwel, A. (2009). Rodzinna Europa po raz pierwszy. Kraków: Universitas.

Michalczyk, S. (2008). Społeczeństwo medialne. Katowice: Śląsk.

Miller, M. (2005). Dziennikarstwo jako narzędzie poznania. W: S. Mocek (red.), Dziennikarstwo, media, społeczeństw. Warszawa: ISP PAN, Collegium Civitas Press.

Piontek, D., Hordecki, B., Ossowski, S. (2013). Tabloidyzacja dyskursu politycznego w polskich mediach. Poznań: Wydawnictwo Naukowe Wydziału Nauk Politycznych i Dziennikarstwa UAM.

Poulet, B. (2011). Śmierć gazet i przyszłość informacji. Wołowiec: Czarne.

Skworz, A., Niziołek, A. (red.). (2010). Biblia dziennikarstwa. Kraków: Znak.

Smoleński, P. (2013). Cycki Dżoany. Pobrane z: http://wyborcza.pl/magazyn/1,132518,13932259,Cycki_Dzoany.html. 
Szot, L. (2013). Dziennikarze mediów lokalnych w Polsce. Między profesjonalizmem a koniecznościa przetrwania. Wrocław: Wydawnictwo Uniwersytetu Wrocławskiego. Środa, M. (2008). Dziennikarskie ciężkie grzechy, Gazeta Wyborcza, nr 54 (5665).

Świat według Naczelnych. (2005). Przekrój, nr 6 (3111).

Taylor, L., Willis, A. (2005). Medioznawstwo. Kraków: Wydawnictwo Uniwersytetu Jagiellońskiego.

Torańska, T. (2006). Zdurniałam. Press, nr 12 (132).

Torańska, T., Purzyńska M. (2013), Ja. My. Oni, Warszawa: Agora.

Żakowski, J. (2009). Reakcje redakcji. Polityka, nr 1 (2686).

Żakowski, J. (2011). Polska śródziemnomorska. Polityka, nr 6 (2793). 